\title{
Sanksi Potong Tangan Bagi Pelaku Tindak Pidana Pencurian Dalam Perspektif Hukum Islam
}

\author{
Oleh: Mardani \\ Dosen Fakultas Hukum Univ. Krisnadwipayana Jakarta \\ e-mail: dani_@telkom.net
}

\begin{abstract}
Cutting hand penalty for theft cases, according to Muslim jurists' view, is a maximum penalty, and hence, not all of such cases deserve for this mode of penalty. In case that the requirements for the implementation of such penalty cannot be found in a theft case, cutting hand may not be implemented and ta'zir shall apply instead. Ta'zir then, is considered as an educative penal system which falls under the authority of the judges to exercise their ijtihad capability.
\end{abstract}

Keywords: sanksi, tindak pidana, hukum Islam

\section{Pendahuluan}

Salah satu aturan Islam yang bertujuan untuk menjaga harta seseorang dari tangan-tangan nakal, ialah Islam mengharamkan mencuri harta milik orang lain. Mencuri adalah perbuatan tercela, berdosa, mengganggu kepentingan orang lain dan bertentangan dengan tujuan pensyari'atan Islam.

Seorang pencuri ketika meniatkan perbuatannya, maka sebenamya ia menginginkan agar usahanya (kekayannya) ditambah dengan kekayaan orang lain, dan ia meremehkan usaha-usaha halal. la tidak mencukupkan dengan hasil usahanya sendiri, melainkan mengharapkan hasil usaha orang lain, agar dengan demikian ia bertambah daya nafkahnya atau tidak bersusah-susah bekerja atau dapat terjamin hari depannya. Dengan perkataan lain, tambahnya usaha atau kekayaan itulah yang menjadi faktor pendorong adanya tidak pencurian. 
Dalam hukum pidana Islam (al-Figh al-Jinai al-Islami) pencurian merupakan suatu bentuk tindak pidana (jarimah/Delik) yang diancam dengan hukuman had, yaitu potong tangan. Hal ini sebagaimana disinyalir oleh Allah SWT. dalam surat al-Maidah ayat 38: Laki-laki yang mencuri dan perempuan yang mencuri, potonglah tangan keduanya (sebagai) pembalasan bagi apa yang mereka kerjakan dan sebagai siksaan dari Allah. Dan Allah Maha Perkasa lagi Maha Bijaksana.

Mengingat masalah interpretasi hukum dan perbedaan pendapat merupakan suatu wilayah yang luas dan kompleks, maka untuk menghasilkan tulisan efektif, efisien, tajam dan obyektif, tulisan ini dibatasi yaitu tindak pidana pencurian yang penulis bahas adalah dengan pendekatan kepada pendapat Mazahib al arba'ah.

Dengan begitu, persoalan-persoalan yang bisa dirumuskan adalah (1) Apakah setiap pencurian dapat divonis dengan sanksi potong tangan atau ada hukum alternatif yang lebih rendah? (2) Bagaimana pendapat para ulama mujtahid (Mazahib al-arba'ah) terhadap persoalan tersebut disertai dalil dan argumentasi mereka? (3) Apa dalil dan argumentasi yang lebih kuat yang digunakan oleh mereka? Tulisan ini berangkat dari asumsi bahwa hukum pidana Islam itu kejam dan tidak sesuai dengan perikemanusiaan dan keadilan.

\section{Pencurian dalam Hukum Pidana Islam}

\section{Pengertian Tindak Pidana Pencurian}

Pengertian Pencurian secara Etimologis yaitu, pencurian asal kata dari saraqa yasriqu-saraqan, wa sariqan wa saraqatan, wa sariqatan wa sirqatan, yang berarti mengambil sesuatu secara sembunyi-sembunyi atau secara terang-terangan. ${ }^{1}$

Ulama mengkategorikan pencurian kepada 2 (dua) macam yaitu pencurian yang diancam dengan hukuman ta'zir adalah pencurian yang tidak terpenuhi syarat-syarat pelaksanaan hukuman Had. Ulama juga mengkategorikan pencurian yang diancam dengan hukuman had, kepada 2 (dua) bagian yaitu pencurian kecil dan pencurian besar.

${ }^{1}$ Fuad Irfan al-Gustami, Munjid Al Tulab, Libanon (Dar Al Masyriq), Cet. 33, 1957, hlm. 315 
Adapun yang dimaksud dengan pencurian kecil secara terminologis adalah: Menurut Abd al Qadir Audah Pencurian kecil adalah mengambil harta orang lain secara sembunyi-sembunyi ${ }^{2}$ sedangkan menurut al Sayid Sabiq yaitu, pencurian kecil adalah pencurian yang wajib divonis dengan potongan tangan ${ }^{3}$ dan dimaksud dengan pencurian besar secara terminologis menurut Abd al Qadir Audah dan al Sayid Sabiq yaitu, pencurian besar adalah mengambil harta orang lain dengan kekerasan dan ini disebut juga dengan merampok atau begal. ${ }^{4}$

Dalam uraian-uraian selanjutnya yang dimaksud dengan pencurian dalam tulisan ini adalah pencurian kecil.

\section{Syarat-syarat Pencuri}

Menurut al Sayid Sabiq, bahwa syarat-syarat pencuri yang divonis dengan sanksi potong tangan adalah sebagai berikut:

a) Taklif (cakap hukum). yaitu, pencuri tersebut sudah balig dan berakal maka tidak divonis potong tangan pencuri gila, anak kecil, karena keduanya tidak mukalaf, tapi anak kecil yang mencuri dapat sanksi yang bersifat mendidik (ta'zir). ${ }^{5}$ Dan Islam tidak menjadi syarat bagi pencuri karena apabila kafir dzimi atau orang murtad mencuri, maka divonis potong tangan begitu sebaliknya.

b) Kehendak sendiri atau Ikhtiar yaitu, bahwa pencuri tersebut mempunyai kehendak sendiri. Seandainya ia terpaksa untuk mencuri, maka tidak dianggap sebagai pencuri, karena paksaan meniadakan ikhtiar tidak adanya ikhtiar menggugurkan taklif.

c) Sesuatu yang dicuri itu bukan barang Syubhat yaitu, sesuatu yang dicuri itu bukan barang Syubhat, jika barang tersebut syubhat, maka pencuri itu tidak divonis potong tangan, oleh karena itu orang tua (Bapak-Ibu) yang mencuri harta anaknya, tidak divonis potong tangan, berdasarkan hadits Nabi Muhammad SAW: kamu dan hartamu milik Bapakmu. ${ }^{6}$

${ }^{2}$ Abdul Qadir Hauda, Al Figh Al Jina'I Al Islami (Qahirah Dar Al-Turas), Jilid I, tth, hlm. 517

${ }^{3}$ Al Sayid Sabiq, Figh Al Sunah Libanon; (Dar El Fikr) Jilid II, hlm. 441

${ }^{4}$ Al Sayid Sabiq, Ibid

${ }^{5}$ Sayid Sabiq, Ibid., hlm. 414

${ }^{6}$ Ibid, hlm. 414 


\section{Rukun Pencurian}

Rukun pencurian adalah sesuatu yang sangat urgen sehingga bila salah satu rukun dari pencurian tidak ada, maka pencurian itu dianggap bukan sebagai pencurian yang sempurna jika pencurian tersebut dianggap bukan sebagai pencurian yang sempurna, maka secara otomatis hukuman had bagi pencuri yaitu potong tangan tidak akan dieksekusi.

Rukun pencurian menurut Abdul Qadir Audah ada 4 (empat) yaitu sebagai berikut:

a) Mengambil secara sembunyi-sembunyi atau secara diam-diam

b) Sesuatu yang diambil itu adalah harta.

c) Harta tersebut milik/kepunyaan orang lain.

d) Ada maksud/niat jahat, atau niat berbuat tindak pidana (mencuri). ${ }^{7}$

Menurut hemat penulis pendapat Ulama di atas, pada prinsipnya sama yaitu pencurian adalah mengambil harta orang lain. Empat Syarat pencurian sebagai berikut:

\section{a) Mengambil Secara Sembunyi-Sembunyi}

Yang dimaksud dengan mengambil secara sembunyi-sembunyi adalah mengambil sesuatu (barang) tanpa diketahui oleh pemiliknya dan tanpa ridhonya, seperti seseorang yang mencuri perhiasan orang lain di rumahnya, ketika pemilik tersebut sedang pergi atau sedang tidur. ${ }^{8}$

Mengambil secara diam-diam itu, dianggap tidak sempurna, bila tidak memenuhi syarat-syaratnya. Adapun syarat-syarat tersebut adalah:

1. Pencuri harus mengeluarkan dari hirz (tempat menyimpan harta yang terjaga).

2. Sesuatu yang dicuri itu harus dikeluarkan dari kekuasaan orang yang kecurian.

3. Sesuatu yang dicuri itu harus sudah ada di dalam penguasaan pelaku tindak pencurian. ${ }^{9}$

Jika ketiga syarat tersebut tidak terpenuhi, maka mengambil tersebut dianggap tidak sempurna. Dan jika syarat tersebut tidak sempurna, maka menurut Hanabilah dan Jumhur Ulama sanksi hukumnya bukan potong tangan tetapi $t a^{\prime} z i r$.

\footnotetext{
${ }^{7}$ Abd. Al Qadir Audah, op. cit, hlm. 518

${ }^{8}$ Abdul Qadir Audah Loc. it

${ }^{9}$ Ibid
} 
Secara teknis mengambil secara diam-diam itu ada 2 (dua) cara yaitu:

a. Dengan cara langsung yaitu si pencuri mengambil sesuatu (barang) dan mengeluarkannya dari hirz, tanpa alat mediator (perantara).

b. Dengan ada sebab yaitu kebalikan dari No. 1 (mengambil dengan alat perantara). Misalnya: Si pencuri menyimpan harta curiannya di atas punggung binatang lalu binatang itu digiring keluar hirz.

Menurut Abu Hanifah, mengambil dengan ada sebab tidak dianggap sebagai pencurian yang sempurna sebab tangan si pencuri itu tidak membawanya keluar hirz. ${ }^{10}$

Adapun menurut Hanabilah yang penting barang (harta yang dicuri itu keluar dari hirz, baik langsung maupun dengan perantara. Hal ini telah digariskan oleh Ibnu Qudamah kapan saja mencuri mengeluarkan barang curiannya dari hirz, maka pencuri wajib dipotong tangannya, baik dia membawa atau dia dilemparkannya diri hirz atau dia ikatkan dengan tali pada binatang, lalu binatang tersebut dia keluarkan atau dia menaruh harta tersebut pada air yang mengalir keluar. ${ }^{11}$

\section{b) Sesuatu yang Diambil itu Harta}

Pada zaman jahiliah (pra Islam), sebelum perbudakan dihapuskan, manusia (budak) dapat dijadikan obyek pencurian. Karena budak dapat diperjual belikan seperti halnya barang, tapi setelah Islam datang dan budak dihapuskan, maka manusia tidak lagi menjadi obyek pencurian. Karena itu menurut Imam Abu Hanifah, Syafi'i dan Ahmad orang yang mencuri manusia tidak dijatuhkan sanksi potong tangan seperti disinyalir oleh Ibnu Qudamah: barang yang dicuri itu harus harta, karena jika yang dicuri itu bukan harta seperti manusia (merdeka) baik yang masih kecil (anak-anak), maupun orang dewasa, maka tidak dipotong tangannya. ${ }^{12}$ Dan begitu juga apa yang digariskan oleh Imam Abu Zahrah yaitu, jika seseorang mencuri manusia merdeka yang masih kanak-kanak, maka menurut Jumhur tidak dipotong tangannya.

Ulama tidak saja mensyaratkan, bahwa yang dicuri itu harta, tapi merekapun mensyaratkan dan mengkriteriakan terhadap harta yang dicuri untuk terpenuhinya sanksi potong tangan. Syarat-syarat tersebut telah ditentukan oleh Abd al Qadar 'Audah sebagai berikut disyaratkan

\footnotetext{
${ }^{10} \mathrm{Ibid}, \mathrm{hlm} .522$

${ }^{11}$ Ibnu Qudamah, Al Mugni (Riyad: Ar riyad Al Hadisah) Juz 8, tt, hlml. 255

${ }^{12}$ Ibnu Qudamah, Ibid., hlm. 244
} 
dalam harta yang dicuri itu ada beberapa syarat yang wajib ada semuanya untuk tegaknya sanksi potong tangan. Syarat-syarat tersebut adalah:

1. Harta itu benda bergerak

2. Harta itu benda berharga (mempunyai nominal)

3. Harta itu tersimpan (terjaga)

4. Harta itu sampai kepada nisabnya. ${ }^{13}$

Setiap barang (harta) yang dicuri, pasti benda itu adalah benda bergerak, baik bergerak karena memang substansi (sifat) benda itu, atau bergerak karena benda itu digerakkan oleh si pencuri. Karena tidak mungkin pencurian akan terjadi bila benda itu tetap (tidak/bukan benda bergerak), karena yang dinamakan pencuri adalah memindahkan suatu benda, lalu mengeluarkan dari hirz dan memindahkan dan penguasaan yang punya benda, kepada penguasaan pelaku pencurian.

Harta (benda) yang bergerak itu ada yang bersifat lunak dan ada juga yang keras contoh benda bergerak yang bersifat lunak adalah uang, cek dan seterusnya. Sedangkan contoh benda bergerak yang bersifat tidak lunak (keras), adalah besi, mobil dan seterusnya. Kedua sifat benda bergerak tersebut bisa dicuri oleh orang lain.

Seperti yang penulis katakan di atas, bahwa benda bergerak itu tidak mesti bergerak karena sifat (substansi) dari benda itu saja, tapi juga dapat bergerak, karena digerakkan oleh si pencuri. Contoh: Bumi dan bangunan yang di atasnya termasuk benda tidak bergerak, tetapi jika seseorang mencuri tanah atau batu yang tadinya melekat pada bumi, maka itu termasuk mencuri benda bergerak.

Mazahib al Arba'ah telah sepakat (konsensus, ijma), bahwa mencuri barang yang tidak berharga (tidak mempunyai nominal), tidak dikenakan sanksi potongan tangan, tapi mereka berbeda pendapat tentang maksud dari benda berharga itu.

a. Menurut Syafi'i, Maliki dan Hambali, bahwa yang dimaksud dengan benda berharga adalah benda yang dimuliakan oleh syara' yaitu bukan benda yang diharamkan oleh syara' seperti mencuri khamar, babi, anjing, bangkai dan seterusnya, karena benda-benda tersebut menurut Islam dan kaum Muslimin tidak ada harganya. Dan karena itu pula mencuri benda yang diharamkan oleh syara', tidak dikenakan sanksi potong tangan sebagaimana telah disinyalir oleh Abd al Qadir Audah: Tidak divonis potong tangan pada pencurian anjing, baik anjing

\footnotetext{
${ }^{13}$ Abd. Al-Qadir Audah, Op Cit, hlm. 543
} 
terdidik (helder) maupun anjing tidak terdidik, meskipun harganya mahal karena haram menjual belikannya. ${ }^{14}$

b. Menurut Abu Hanifah, bahwa yang dimaksud dengan benda berharga adalah benda yang dapat menyebabkan seseorang menjadi kaya atau orang itu bisa bakhil (pelit) dengan sebab benda itu. Karenanya mencuri benda-benda yang dianggap remeh oleh adat, tidak dikenakan sanksi potong tangan. Hal ini telah disinyalir oleh Abdu al Qadir 'Audah: Pada masa Rasulullah SAW, pencuri barang (benda) yang dianggap remeh (ringan) tidak dipotong tangannya. ${ }^{15}$

Dalam redaksi lain Imam Abu Zahrah mengatakan bahwa pencuri barang (benda) yang oleh adat manusia dianggap remeh, dia tidak dikenakan sanksi potongan tangan. Contoh benda itu dianggap remeh adalah. Apa yang telah dicontohkan di dalam hadis riwayat Ahmad bin Hambal sebagai berikut: Dari Rafi' bin Khadij ia berkata: Aku mendengar Rasulullah SAW. bersabda: Tidak dikenakan sanksi potong tangan orang yang mencuri buah dan bara api. ${ }^{16}$ (HR. Ahmad bin Hambal).

Yang dimaksud buah pada hadis di atas adalah buah yang bergelantungan di pohonnya, tidak dijaga (tidak ada yang hirz) dan buah tersebut tidak sampai kepada nisabnya. Dari Amir bin Syuaib dari ayahnya dari kakeknya, ia berkata: "Rasulullah pernah ditanya tentang buahbuahan yang bergelantungan di pohon". Lalu Rasulullah menjawab: "Barang siapa melempar sekedar kebutuhannya, tanpa mengambil (memenuhi) kantong kain (tas)nya, maka tidak apa-apa baginya. Dan barang siapa mengeluarkan (membawa), maka dia harus mengganti seharga barang itu dan dikenakan sanksi. Dan barang siapa mencuri setelah dibawa ke tempat penjemurannya, dan kadernya seharga perisai, maka baginya sanksi potong tangan. (H.R. Al Nasa'i) ${ }^{17}$

Malik telah meriwayatkan dari Ibnu Syihab dari Sofwan bin Abdillah bin Sofyan Umayah dikatakan kepadanya: Bahwa siapa yang tidak hijrah, maka ia celaka, lalu Sofwan bin Umayah datang ke Madinah dan ia tidur di dalam masjid dengan menggelarkan selendang jubahnya. Tiba-tiba datang pencuri dan mengambil jubah (yang ada di kepalanya) lalu Sofwan

\footnotetext{
${ }^{14} \mathrm{Ibid}$, hlm. 550

${ }^{15}$ Ibid, hlm. 547

${ }^{16}$ Imam Ahmad bin Hambal, Al Musnad, (al Maktab al-Islami), Juz Ketiga, tt, hlm. 463

${ }^{17}$ Imam Nasai Sunan al Nasai (Mesir, Mustafa Babil Halabi), 1964 M/1394 H,
} Jilid 3 hlm. $76-79$ 
menangkap pencuri tersebut kemudian membawanya kepada Rasulullah SAW. Rasulullah bertanya kepadanya: “apakah kamu mencuri selendang ini" dia menjawab: ya. Maka Rasulullah SAW memerintahkan kepada Sofwan untuk memotong tangannya (pencuri), lalu Sofwan berkata: ya Rasulullah, saya tidak menghendaki ini (potong tangan), tapi selendang ini biar saya sedekahkan saja kepadanya. Maka Rasulullah SAW bersabda: Wah, hal itu saya tidak menduga sebelumnya". (H.R. Malik) ${ }^{18}$

Menurut Jumhur Ulama, bahwa hadis-hadis tersebut di atas menunjukkan adanya hirz, sebagai salah satu syarat bagi harta yang dicuri untuk dikenakan sanksi potong tangan bagi pencuri. Sebab dalam hadis di atas Rasulullah SAW menghubungkan sanksi potong tangan dengan mencuri buah setelah dibawa ke tempat penjemurannya. Penjemuran ini adalah hirz bagi buah tersebut. Kemudian hadis Sofwan menunjukkan adanya hirz, yaitu dengan menjadikan selendang tersebut, sebagai bantal. Hal ini dikehendaki oleh Imam Syafi'i. Jubah Sofwan ada terjaga, karena dia membaringinya. ${ }^{19}$

Menurut kesepakatan (konsensus) Ulama bahwa hirz (tempat penyimpan harta) dikatagorikan kepada tiga macam, yaitu:

a. Hirz bi al Makan yaitu tempat penyimpanan harta yang berbentuk kontruksi (bangunan), seperti: rumah, toko, kandang bagi binatang dan seterusnya.

b. Hirz bi Nafsihi yaitu penyimpanan harta yang dijaga oleh diri sendiri seperti cincin yang sedang dipakai.

c. Hirz bi al Hafiz atau hirz bigairihi yaitu suatu tempat yang bukan disediakan untuk menyimpan barang akan tetapi tempat itu bisa menjadi hirz jika ada yang menjaganya seperti menyimpan barang di lapangan terbuka, masjid dan seterusnya.

Yang dijadikan dasar hukum bahwa syarat harta yang dicuri itu sampai nisabnya adalah beberapa sabda Rasulullah SAW sebagai berikut: Dari Ibnu Umar dari Nabi SAW, sesungguhnya beliau telah menolong (tangan pencuri) pada pencurian perisai seharga tiga dirham. (H.R. al Bukhari) ${ }^{20}$ Dari Aisyah, bersabda Nabi SAW, dipotong tangan (pencuri yang mencuri) pada seperempat dinar atau lebih. (H.R. al Bukhari) ${ }^{21}$

\footnotetext{
${ }^{18}$ Imam Malik, Auza'al Masalik. (Beirut: Darul Fikr) Juz 13, tt, hlm. 295-298

${ }^{19}$ Muhammad Idris Asy Syafi' I Al-Um Mesir: Al Faniyah Muttahidah 1961 M/ 1981 H, Jilid 6, hlm. 148

${ }^{20}$ Imam Bukhari,

${ }^{21}$ Ibid, hlm. 199
} 
Dari Nabi bersabda SAW bersabda: Tidak dikenakan sanksi potong tangan pencuri, pada pencurian yang kurang seharga perisai, lalu Aisyah bertanya, beberapa harga perisai? Lalu beliau menjawab seperempat dinar atau lebih. (H.R. al Bukhari) ${ }^{22}$

Berdasarkan beberapa hadis yang penulis kemukakan di atas, maka menurut kesepakatan mazahib al Arba'ah, bahwa merupakan salah satu syarat untuk dilaksanakannya sanksi potong tangan adalah harta yang dicuri harta itu harus sampai nisabnya. Jumhur Ulama telah sepakat adanya nisab pencurian. Tetapi mereka berbeda pendapat dalam menetapkan kadarnya. Menurut Imam Syafi'i kadarnya adalah seperempat dinar ${ }^{23}$ atau lebih sebagaimana disinyalir olehnya di dalam kitab Al Um: Siapa yang ingin memotongnya, maka kadarnya harus sampai seperempat dinar atau lebih. ${ }^{24}$

Jika yang dicuri itu bukan emas atau perak, maka menurut Imam Malik kadarnya diukur kepada harga perak yaitu tiga dirham. Sebagaimana disinyalir oleh Ibnu Rusyd: Imam Malik berkata dalam perkataannya yang masyhur "Ditentukan dengan beberapa dirham bukan dengan seperempat dinar. ${ }^{25}$

Sedangkan menurut Imam Syafi'i kadarnya ditentukan dengan harga dinar, sebab harga dinar pada waktu itu menjadi ukuran, sebagaimana ia berkata: Pencuri tidak dipotong (tangannya), sehingga ia mencuri sama dengan seperempat dinar paling sedikit. ${ }^{26}$

Adapun Ulama Hanabilah menetapkan seperempat dinar atau lebih, sebagaimana telah disinyalir oleh Ibnu Qudamah: Dan menurut kami adalah sebagaimana sabda Nabi SAW: tidak divonis, potong tangan kecuali pada seperempat dinar atau lebih. ${ }^{27}$

${ }^{22}$ Imam Bukhari, Op Cit, hlm. 74

${ }^{23}$ Satu dinar sma dengan 3.879 ems murni, Ibnu Taimiyah, al-Siasah al-Syar'iyyah fi islahiahli Ra'yi wa al Ra'yah, 'alih Bahasa Muhammad Munawwir al Zahidi, (Surabaya, Pen. Dunia Ilmu, Cat. I, 1418 H, 1997 M

${ }^{24}$ Imam Syafi'i, Op Cit, hlm. 147

${ }^{25} \mathrm{Ibnu}$ Rusyd, Bidyahtal Mujtahod (Beirut: Dar al Fikr) Juz 2, tt, hlm. 355

${ }^{26}$ Imam Syafi'i, Loc Cit

${ }^{27}$ Ibnu Qudamah, Op Cit, hlm. 81 


\section{Harta itu Milik Orang Lain}

Untuk ada jarimah pencurian, maka kedudukan harta yang dicuri itu harus milik orang lain. Sebab jika harta itu milik si pencuri, maka tidak dianggap sebagai pencurian walaupun mengambilnya secara diam-diam.

Yang dimaksud dengan milik si pencuri di sini yaitu menjadi hak milik pencuri ketika terjadi pencurian. Akan tetapi kalau hak milik itu terjadi sebelum pencurian, kemudian ia melepaskannya sebelum mencuri, maka si pencuri tetap diminta pertanggung jawaban tentang pencurian tersebut.

Sebaliknya, jika pencuri pada mulanya tidak mempunyai hak milik terhadap sesuatu benda, kecuali ia mempunyai hak milik pada benda itu ketika mencurinya. Jika hak milik itu timbul sebelum si pencuri mengeluarkan barang dari hirz, maka ia tidak diminta pertanggung jawaban tentang hal itu. Akan tetapi jika hak milik itu timbul setelah ia mengeluarkan barangnya dari hirz, maka ia diminta pertanggung jawaban, sebab syarat untuk hilangnya pertanggung jawaban pidana dalam hal ini ialah hirz. Hal ini dikemukakan oleh Abd al Qadir Audah: Dan syarat untuk hilangnya pertanggung jawaban pidana yaitu adanya hak milik sebelum (si pencuri) mengeluarkan dari hirz. Karena jika hak milik itu ada setelah (si pencuri) mengeluarkan dari hirz, maka tidak akan menghapus pertanggung jawaban pidana. ${ }^{28}$

\section{Ada Niat Jahat}

Mengambil sesuatu secara diam-diam, bisa dianggap sebagai pencurian bila ada niat jahat. Adapun pengertian niat jahat adalah: "Terpenuhinya unsur niat jahat itu apabila si Jani (Pencuri) mengambil sesuatu dan ia mengetahui bahwa mengambilnya itu diharamkan." 29

Oleh karena itu jika mengambil sesuatu yang hukumnya mubah atau yang telah dibuang, maka dalam hal ini tidak ada sanksi sebab tidak ada niat jahat. Seperti mengambil puntung rokok atau mengambil sesuatu di tempat sampah atau di tempat lain, asal si pencuri (jina'i) mengetahui benda tersebut telah dibuang oleh pemiliknya, atau mengambii sesuatu dengan keyakinan, bahwa pemiliknya akan merestuinya. Maka dalam hal ini yang demikian itu tidak dianggap sebagai pencurian sebab tidak ada niat jahat.

\footnotetext{
${ }^{28}$ Abdul Qadir Audah, Op Cit, hlm. 589

${ }^{29} \mathrm{Ibid}, \mathrm{hlm} .608$
} 
Untuk Jarimah pencurian ini, dalam niat jahat harus ada niat untuk memilikinya. Jika tidak ada niat untuk memilikinya, misalnya untuk dirusakkan, maka dalam hal ini bukan pencurian, tetapi pengrusakkan jika merusakkannya di dalam hirz. Tetapi jika merusaknya setelah dibawa ke luar hirz, maka tetap ia sebagai pencurian, demikian menurut Jumhur.

\section{Doktrin Ulama Tentang Pencurian}

\section{Sanksi Hukum Bagi Tindak Pidana Pencurian}

Ulama telah sepakat bahwa sanksi pencurian adalah potong tangan. Hal ini berdasarkan Q.S. Al Maidah Ayat 38: Laki-laki yang mencuri dan perempuan yang mencuri, potonglah tangan keduanya (sebagai) pembalasan bagi apa yang mereka kerjakan dan sebagai siksaan dari Allah. Dan Allah Maha Perkasa lagi Maha Bijaksana. (Qs. Al-Maidah: 38)

Potong tangan adalah merupakan sanksi yang sangat asas (mendasar) dalam pencurian. Oleh karenanya tidak hapus dengan adanya pemaafan, baik dari korban maupun dari penguasa. Sanksi ini tidak boleh diganti dengan sanksi lain yang lebih ringan daripadanya. Hal ini berdasarkan hadis Rasulullah SAW riwayat Imam Muslim: Dari Aisyah R.A. sesungguhnya Rasulullah SAW bersabda: ... Apakah engkau meminta syafa'at dari had-had Allah? Kemudian Rasulullah SAW berkhutbah lalu bersabda: Wahai sekalian manusia: Sesungguhnya hancurnya orang-orang sebelum kamu, bahwasanya keadaan mereka apabila orang terhormat mencuri, mereka meninggalkannya (potong tangan). Dan apabila kaum du'afa mencuri mereka menegakkan sanksi potong tangan kepadanya. (H.R. Muslim).

Sanksi tersebut dikenakan terhadap pencuri yang syarat dan rukun pencurian tersebut terpenuhi secara sempurna. Dan seandainya tidak terpenuhi, maka sanksi hukumnya adalah $t a^{\prime} z i r$.

\section{Sanksi Pencurian Dalam Lingkup Keluarga}

Menurut Syafi'i, Hanabillah dan Hanafiyah bahwa anak yang mencuri harta orang tuanya atau sebaliknya, tidak dieksekusi potong tangan, sebab ia berarti mencuri hartanya sendiri. Hal ini telah disinyalir oleh Ibnu Qudamah versi Hanabillah: Ayah tidak dieksekusi potong tangan, bila mencuri harta anaknya. Karena berarti ia mengambil hartanya sendiri. Begitu juga ibu tidak dipotong tangan, bila mencuri harta anaknya. 
Adapun dalil mereka gunakan sebagai hujjah adalah hadis Rasulullah SAW riwayat Ibnu Majah. Dan hadis tersebut adalah telah menceritakan kepada kami Hisyam bin Amar, telah menceritakan Isa bin Yunus, telah menceritakan Yusuf bin Ishak dari Muhammad bin Munkadir dari Jabir bin Abdullah. Bahwa seseorang telah berkata: Wahai Rasulullah SAW, sesungguhnya saya mempunyai harta dan anak. Dan ayah saya sangat membutuhkan harta saya. Maka Rasulullah SAW bersabda: kamu dan hartamu adalah milik (untuk) bapakmu.

Begitu juga, tidak divonis potong tangan, suami yang mencuri harta isterinya atau sebaliknya. Mereka berhujjah dengan amal (asar) sahabat Umar bin Khatab. Dan amal sahabat tersebut adalah telah memberitahu Kami Malik dari Ibnu Syihab dari Saib bin Yazib, bahwasanya "Abdullah bin Amir Al Hadramani bersama pembantunya (khadam) telah menghadap kepada Umar bin Khatab R.A. lalu berkata: "Potonglah tangan khadam ini, karena ia telah mencuri". Lalu Umar R.A. bertanya kepadanya, apa yang ia curi, ia menjawab: "Khadam ini telah mencuri cermin milik isteriku yang harganya enam dirham". Kemudian Umar berkata: Aku mengharapkan, agar ia tidak divonis potong tangan, khadammu mencuri hartamu.

Asar sahabat Umar R.A. di atas menurut Hanafiyah, sebagian dari golongan Syafi'iyah dan Hanabilah, dapat juga dijadikan hujjah untuk tidak divonis potong tangan bagi suami yang mencuri harta isterinya atau sebaliknya hal ini telah disinyalir oleh Abu Hanifah: Apabila pembantu tidak divonis potong tangan, maka suami lebih utama dalam rukhsah (keringanan) ini.

Berdasarkan kepada asar sahabat Umar R.A. maka Imam Syafi'i berpendapat yaitu: Untuk ikhtiyat (hati-hati), tidak divonis potong tangan, suami yang mencuri harta isterinya, istri yang mencuri harta suaminya dan budak yang mencuri harta sesama budak, berdasarkan asar dan syubhat dalam harta.

Menurut Hanabilah, bahwa anggota keluarga termasuk kerabat yang tidak diterima persaksiannya dan saling waris mewarisi yang tanpa hijab. Oleh karenanya tidak divonis potong tangan, bila terjadi pencurian dalam lingkup keluarga. Hal ini telah digariskan oleh Ibnu Qudamah dalam kitab Al-Mugni yaitu, oleh karena masing-masing keduanya saling mewarisi tanpa hijab dan tidak diterima persaksiannya, serta menurut adat keluasan (kebebasan) pada harta lainnya, (harta suami atau sebaliknya), maka orang tua serupa dengan anak dalam hal harta. 
Selain hadis Rasulullah SAW dan Asar sahabat yang mereka jadikan hujjah, mereka juga mengemukakan dalil-dalil Al-Qur'an Ibnu Qudamah versi Hanabilah mengemukakan Q.S. al Nisa ayat 36 yaitu, sembahlah Allah dan janganlah kamu mempersekutukan-Nya dengan sesuatupun. Dan berbuat baiklah kepada dua orang Ibu Bapak ... (Qs. Al Nisa; 36)

Ayat di atas menegaskan tentang kewajiban anak harus berlaku baik terhadap kedua orang tuanya. Oleh sebab itu menurut Hanabilah bila sanksi potong tangan diberlakukan kepada orang tua yang mencuri harta anaknya, maka secara otomatis hak orang tua dan kewajiban anak tidak akan tercapai.

Argumentasi lain yang dikemukakan oleh Imam Abu Hanifah adalah bahwa seandainya sanksi potong tangan diberlakukan pada pencurian lingkup keluarga, maka ini dapat memutuskan tali kekeluargaan. Maka yang demikian itu hukumnya haram, berdasarkan kaidah usul fiqih yaitu, sesuatu hal yang membawa kepada haram, maka hukumnya haram.

Adapun menurut Malikiyah, hanya ayah saja yang dapat dijatuhkan hukuman potong tangan, bila ia mencuri harta anaknya. Sedangkan jika yang mencuri itu kerabat lainnya, maka sanksi potong tangan harus tetap ditegakkan. Hal ini telah disinyalir oleh Ibnu Rusyd yaitu, Imam Malik berpendapat dalam masalah ini, bahwa ayah tidak dijatuhi sanksi potong tangan, bila ia mencuri harta anaknya saja, sedangkan kepada orang selainnya, harus tetap ditegakkan sanksi potong tangan.

Hujjah yang dijadikan oien Malikiyah adalah hadis Nabi Muhammad SAW riwayat Ibnu Majah dari Jabir yang berbunyi yaitu, kamu dan hartamu adalah milik (untuk) ayahmu. (H.R. Ibnu Majah)

Menurut mereka hadis tersebut menunjukkan bahwa hanya bapak saja yang mempunyai hak terhadap anaknya, tidak sebaliknya.

Adapun suami yang mencuri harta isterinya atau sebaliknya menurut Malikiyah, Hanabilah dan Qaul Jadid (pendapat baru) Syafi'iyah adalah hartanya tersimpan dalam hirz atau sesuatu tempat (rumah) yang tidak didiami oleh mereka berdua, maka sanksinya adalah potong tangan. Hal ini disinyalir oleh Ibnu Rusyd yaitu, Imam Malik berkata: Bila harta itu ada di rumah yang terpisah (tidak didiami oleh mereka berdua, bersamasama), maka sanksi orang yang mencuri harta sohib (teman dekat) itu adalah potongan tangan. 
Mazahib al Arba'ah telah konsensus (ijma) bahwa hirz merupakan salah satu syarat bagi harta yang dicuri, untuk dijatuhkan sanksi potong tangan bagi pencuriannya. Dan hirz itu gugur kedudukannya sebagainya hirz, jika adanya izin masuk dari pemiliknya. Hal ini telah digariskan oleh Imam Abu Hanifah yaitu, tidak divonis potong tangan terhadap orang yang mencuri dalam lingkup keluarga karena secara adat, masing-masing mereka boleh masuk (ke rumah keluarganya) tanpa izin. Karena di sana ada izin masuk, maka terjadilah pencuri pada hirz. Terlebih-lebih bahwa jika mereka divonis potong tangan dengan sebab mencuri, maka itu dapat menimbulkan putusnya tali persaudaraan. Dan hal itu haram.

Dalam masalah ini, Abu Hanifah berhujjah kepada Q.S. Al Nur: 61: Tidak ada halangan bagi dirimu sendiri, makan (bersama-sama mereka) di rumah kamu sendiri atau di rumah bapak-bapakmu, di rumah ibuibumu, di rumah saudara-saudaramu yang laki-laki, di rumah saudaramu yang perempuan, di rumah saudara bapakmu yang laki-laki di rumah saudara bapakmu yang perempuan, di rumah saudara ibumu yang lakilaki di rumah saudara ibumu yang perempuan, di rumah yang kamu miliki kuncinya atau di rumah kawan-kawanmu ... (Qs. Al Nur; 61)

Ayat tersebut di atas, membolehkan kepada kita untuk makan di rumah mereka. Oleh karenanya menurut Abu Hanifah adanya izin masuk ke rumah mereka. Sehingga kedudukan hirz gugur dengan adanya izin masuk itu.

Menurut Al Maragi bahwa yang dimaksud dengan kata-kata buyutiqum dalam ayat di atas adalah mencakup rumah anak dan isteri. Dan statemen beliau, maksudnya adalah tidak berdosa atasmu, makan di rumah isteri-isterimu dan keluarga-keluargamu. Dalam hal ini mencakup juga rumah anak-anakmu, karena rumah anak itu rumah orang tua juga.

Berdasarkan kepada pendapat al Maragi tersebut, maka penulis berpendapat bahwa orang tua yang mencuri harta anaknya atau sebaliknya dan suami yang mencuri harta isterinya atau sebalikya, tidak dijatuhkan sanksi potong tangan.

\section{Teknis Eksekusi Potong Tangan}

Ulama al Mazahib Al-Arba'ah berbeda pendapat dalam menetapkan teknis eksekusi potong tangan pada diri pencuri.

Menurut Hanafiyah dan Hanabilah, yang dipotong tangan itu tangan kanan dan kaki kiri. Dipotong tangan kanan pada pencurian yang pertama dan kaki kiri pada pencurian yang kedua kali. Jika terjadi pencurian yang ketiga kalinya, maka tidak dipotong, tetapi dipenjara 
selama waktu tidak ditentukan, sampai meninggal dunia atau sampai nampak taubatnya. Mereka berargumentasi kepada amal sahabat Ali bin Abi Thalib R.A.: Telah menceritakan kepada Abu Mu'syir dari Said bin Abu Said Al Maqbiri dari ayahnya, ia berkata: "Aku telah menghadiri Ali bin Abi Thalib membawa seorang laki-laki yang putus sebelah tangan dan kakinya, yang pernah mencuri. Ia (Ali) bertanya kepada sahabatnya, bagaimana pendapat kalian tentang hal ini. Mereka menjawab, potong ya Amirul Mu'minin. Ali R.A. berkata: “Aku bunuh dia jika kudapati dia membunuh. Sebab dengan apa dia memakan makanan, dengan apa dia berwudlu untuk shalat, dengan apa bersuci dari junub, dengan apa ia berdiri untuk keperluannya. Maka Ali R.A. memasukkan dia ke penjara selama beberapa hari, kemudian mengeluarkannya. (H.R. Baihaqi).

Menurut Imam Syafi'i dan Malik dipotong kedua lengan dan kakinya. Dipotong tangan kanan pada pencurian yang pertama dan kaki kiri pada pencurian yang kedua. Kemudian dipotong tangan kiri pada pencurian yang ketiga dan kaki kanan pada pencurian yang keempat. Kemudian jika mencuri lagi yang ke lima, maka dipenjarakan seumur hidup atau sampai nampak taubatnya.

Imam Syafi'i berargumentasi kepada amal sahabat Abu Bakar Sidiq yang menghukumi seorang pencuri ahli Yaman, yang kaki dan tangan telah putus. Kemudian beliau menjatuhkan hukum potong tangan kepadanya. Berdasar asar sahabat tersebut Imam Syafi'i berpendapat: Maka dengan ini kami mengambil (hukum). Apabila seorang pencuri mencuri yang pertama kalinya, maka aku potong tangan kanannya sampai pergelangan kemudian digarang dengan api. Jika dia mencuri yang kedua kalinya, maka aku potong kaki kirinya sampai pergelangan kemudian digarang. Jika dia mencuri yang keempat kalinya, maka aku potong kaki kanannya sampai pergelangan, kemudian digarang. Jika dia mencuri yang kelima kalinya, maka dia dipenjara.

Adapun pendapat Imam Malik sendiri telah dikutip oleh Ibnu Rusyd sebagai berikut: Jika pencuri mencuri yang ketiga kalinya, maka aku potong tangan kirinya. Kemudian jika dia mencuri yang keempat kalinya, maka aku potong kaki kanannya. 


\section{Analisa Perbandingan Mazhab}

\section{Standar Nisab Harta yang Dicuri}

Untuk tegaknya sanksi potong tangan bagi tindak pidana pencurian, maka harus ada empat syarat:

a) Harta itu benda bergerak

b) Harta itu benda berharga (mempunyai nominal)

c) Harta itu tersimpan (terjaga)

d) Harta itu sampai kepada nisabnya.

Ulama telah sepakat tentang harta itu benda bergerak, berharga (mempunyai nominal) dan tersimpan (terjaga), tetapi mereka berbeda pendapat dalam hal batasan nisabnya. Perbedaan tersebut disebabkan kepada:

1. Banyaknya, periwayatan hadis Rasulullah SAW yang menjelaskan nisab pencurian, seperti: Dari Ibnu Urnar dari Nabi SAW, sesungguhnya beliau telah memotong (tangan pencuri) pada pencuri perisai seharga tiga dirham. (H.R. Bukhari). Dari Aisyah, bersabda SAW, dipotong tangan (pencuri yang mencuri) pada seperempat dinar atau lebih. (H.R. Bukhari). Dari Nabi SAW bersabda: tidak dikenakan sanksi potong tangan pencuri, pada pencurian yang kurang seharga perisai, lalu Aisyah bertanya, berapa harga prisai? Lalu beliau menjawab seperempat dinar lebih atau lebih (H.R. Nasa'i). Dari Abu Hurairah dari Nabi Muhammad SAW, bahwa Nabi Muhammad SAW bersabda: Allah melaknat pencuri telor, lalu dipotong tangannya, dan pencuri tali, lalu dipotong tangannya. (H.R. Bukhari)

2. Ketidak jelasan ukuran harga Al Mijan sebagai ukuran nisab harta yang dicuri.

3. Lafaz Al Mijan adalah lafaz yang asing di kalangan para mujtahidin Mayoritas ulama mengamalkan/menggunakan hadis Aisyah di atas. Sesungguhnya nisab pencurian itu seperempat dinar. Apabila seseorang mencuri dirham atau perhiasan, maka distandarkan dengan dinar, jika harganya sampai seperempat dinar, maka dipotong tangannya. Begitu juga menurut Al-Khitabi: la berkata: Dan pendapat yang pertama, yaitu yang kembali kepada seperempat dinar itu lebih saheh. Karena yang asal standar pada waktu itu adalah dinar. Adapun hadis Abu Hurairah di atas menurut Al-A'masy, bahwa yang dimaksud dengan telor adalah besi dan dimaksud dengan tali adalah sesuatu yang sama dengan dirham. 
Interpretasi al' Amasy di atas adalah sebagai upaya mengkompromikan hadis-hadis Nabi SAW yang bertentangan pemahamannya.

\section{Pencurian Dalam Lingkup Keluarga}

Menurut mayoritas 'Ulama, bahwa orang tua yang mencuri harta anaknya atau sebaliknya tidaklah divonis dengan sanksi potong tangan, sebagaimana keterangan Dr. Wahbah Al-Zuhaili, yaitu, sesungguhnya tindak pidana pencurian yang demikian (harta yang syubhat) bukanlah pencurian yang sempurna, karena itu tidak dituntut oleh sanksi yang sempurna pula .... Dan tidak dipotong tangan, orang tua yang mencuri harta anaknya (terus keturunan ke bawah), karena harta syubhat dalam pemilikannya, begitu pula tidak dipotong tangan orang tua yang mencuri harta anaknya (terus keterusan ke atas), karena ada izin masuk rumah (hirz). Ringkasnya tidak dipotong tangan pada harta syubhat dalam kepemilikannya berdasarkan hadis "tinggalkanlah sanksi had dalam syubhat inilah mazhab Hanafiyah, Syafi'iyah dan Hanabilah.

Isteri yang mencuri harta suaminya atau sebaliknya, menurut Jumhur Ulama tidak dipotong tangannya, karena :

1. Ada Syubhat dalam harta

2. Adanya ikhtilat (pencampuran) dalam harta

3. Dari ulama al Mazahib at Arba'ah dapat dipahami bahwa hirz merupakan salah satu syarat bagi harta yang dicuri, untuk dijatuhkan potong tangan bagi pencurinya. Dan hirz gugur kedudukannya sebagai hirz bila ada izin yang masuk dari pemiliknya.

Tidak dipotong tangan terhadap orang yang mencuri dalam lingkup keluarga, karena bila hukuman potong tangan dilaksanakan, maka akan timbul putusnya hubungan silaturahmi dan hal ini dilarang oleh syari'at.

\section{Pencurian Berulang Kali}

Menurut Hanafiah dan Hanabilah: jika terjadi pencurian yang ketiga kalinya, maka tidak dipotong tangan, tetapi dipenjara selama waktu yang tidak ditentukan, sampai meninggal dunia atau sampai nampak taubatnya. la berargumentasi pada kepada amal sahabat Ali bin Abi Talib yaitu, telah menceritakan kepada kami Abu Mu'syir dari Said bin Abi Said AI-Maqbari dari ayahnya, ia berkata: “Aku telah menghadiri Ali bin Abi Talib membawa seorang laki-laki yang putus sebelah tangannya dan akkinya, yang pernah mencuri. la (Ali) bertanya kepada para sahabatnya, 
bagaimana pendapat kalian tentang hal ini? Mereka menjawab, potong wahai Amirul Mukminin. Ali berkata: Aku bunuh dia jika kudapati dia membunuh, sebab dengan apa dia memakan makanan, dengan apa dia berwudlu untuk shalat, dengan apa dia bersuci dari junub, dengan apa dia berdiri untuk keperluannya. Maka Ali RA memasukkan dia ke penjara selama beberapa hari, kemudian mengeluarkannya. (H.R. Baihaqi).

Menurut Imam Syafi'i dan Malik dipotong tangan dan kakinya. Dipotong tangan kanan pada pencurian yang pertama dan kaki kiri pada pencurian kedua. Kemudian dipotong tangan kiri pada pencurian yang ketiga dan kaki kanan pada pencurian yang keempat. Kemudian jika mencuri lagi yang kelima kalinya, makan dipenjarakan seumur hidup atau sampai nampak taubatnya. Imam Syafi'i berargumentasi kepada amal sahabat Abu Bakar Sidiq yang menghukumi seorang pencuri ahli yaman, yang kaki dan tangannya telah putus. Kemudian beliau menjatuhkan hukum potong tangan kepadanya. Berdasarkan atsar sahabat tersebut Imam Syafi'i berpendapat: Maka dengan ini kami mengambil (hukum). Apabila seorang pencuri mencuri yang pertama kalinya, maka aku potong tangan kananya sampai pergelangan kemudian digarang dengan api. Jika dia mencuri yang kedua kalinya, maka aku potong kaki kirinya sampai pergelangan kemudian digarang. Jika dia mencuri yang keempat kalinya, maka aku potong kaki kanannya sampai pergelangan, kemudian digarang. Jika dia mencuri yang kelima kalinya, maka dia dipenjara.

\section{Penutup}

Setelah dikupas sanksi potong tangan bagi tindak pidana pencurian dalam perspektif Hukum Islam, maka dapat menarik beberapa kesimpulan sebagai berikut: Sanksi potong tangan dalam tindak pidana pencuri menurut Ulama merupakan sanksi maksimal, oleh karena itu tidak setiap pencurian dikenakan dan dijatuhkan sanksi potong tangan. Ini terbukti dengan ditentukannya syarat dan rukun pencurian yang sangat ketat. Seandainya salah satu syarat atau rukun pencurian tersebut tidak terpenuhi secara sempurna, maka sanksinya tidak potong tangan, tetapi tetap diberikan sanksi alternatif yang disebut dengan $t a^{\prime} z i r$, yaitu sanksi yang bersifat mendidik, yang tidak ditentukan oleh syari'at, hakim mempunyai otoritas mutlak melalui ijtihadnya untuk dapat memberikan jenis hukuman $t a^{\prime} z i r$ tersebut. 
Begitu juga tidak dapat diberikan sanksi potong tangan terhadap pencurian dalam lingkup keluarga, seperti orang tua mencuri harta anaknya atau sebaliknya, isteri mencuri harta suaminya atau ssebaliknya dan pembantu mencuri harta majikannya, karena masing-masing diantara mereka mempunyai hak nafkah, yaitu pada harta anak ada hak orang tua atau sebaliknya, alasan lain yang diungkapkan oleh Ulama adalah karena secara syari'at orang tua dan anak tidak diterima persaksiannya di pengaadilan dan merupakan ahli waris yang tidak terhijab (terhalang), dan karena adanya syubhat dan ikhtilaf (percampuran) dalam harta.

\section{Daftar Pustaka}

Abu Ishaq Ibrahim Ibn Musa, al Lakhim al-Ghamathi al-Syatibi, AlMuwafaqat fi' Ushul al Ahkam. Beirut: Dar AI-Fikr, $1341 \mathrm{H}$

Abu Zahrah, Al Imam Muhammad. Usul Al Figh. Dar al Fikr, tt, 1377 H/ $1958 \mathrm{M}$.

'Audah, 'Abdul Qadir. AI-Figh al-Jina'i al-lslami. Qahirah: Dar al-Turan, T.Th., jilid I

Balitilyausi, Sayid al. al-Tanbih 'ala al-'Ashhab 'allati 'aniaba al-ikhtilaf baina al-muslimin fi 'aro'ihim wa Madzhabihim wa Ttiqadihim. AI-Qahirah: Dar al-l'tisham, tahun 1978

Bahsani, Ahmad Fathi, Dr, Al Mausuah Al Jinaiyah Nahdah al Arabiyah. Juz 3, tth

Bukhari, Imam. Shahih al-Bukhari. Beirut: Dar al-Fikr, jilid viii, T.Th.

Bustami, al Fuad Ifram, Munjid al Tulab, Libanon: Dar Al Masyriq, cet. 33, 1957

Bidayah Al Sana'l. Dar Al Fikr, Juz 7, tth, tt

Dadiri, al. al-Svarah al-Kabir. Dar al-Fikr, juz iv, T.Th.

Dahlawi, Walitullah Syekh al. Lahirnya Madzhab-Madzhab Figh. Terj Murjiyo Nurkholis, Bandung: Remaja Rosda Karya, tahun 1994

Din Abdu, Shafi al., Qawaid al 'Ushul wa Ma'aqid al 'Ushul. Beirut: Alam al Kutub, 1986 
Djamil, Faturrahman, Filsafat Hukum Islam, Jakarta: Logos Wacana llmu, cet. 1, 1997

Ghazali, Imam, al., al-Mustashfa min 'llmi al-'Ushul Libanon: Dar al-Kutub al-'llmiyyah, cet. I, 1933

Ghazali, M. Bahri, Drs, MA dan Djumadris, Drs, Perbandingan Mazhab. Jakarta: Pedoman llmu Jaya, cet. Pertama, 1992

Haito, Muhammad Hasan, Al Wajiz fi 'Ushu! al Tasyri' al-lslami. Beirut: Muassasah al Risalah, 1983

Hambal, Ahmad Ibn, Al Musnad. (al Maktab al-Islami), Juz Ketiga, tt

Hanafi, Ahmad, MA, Asas-asas Hukum Pidana Islam. Jakarta: Bulan Bintang, 1967

Hasan, Ali, M. Perbandingan Madzhab. Jakarta: Penerbit PT. Raja Grafindo Persada, 1995

Jaziri, Abdul Rahman al. al-Figh 'ala Madzahib al-'Arba'ah. Beirut: Dar alFikr, tth, cet. I, juz ke-5

Jundi, Abdul Halim 'Imam Abu Hanifah. Dar al-Ma'arif, tth, tt, cet. ii

Kahlani, Muhammad Ismail al. Subul al-Salam. Beirut: Daral-Fikri, tth., juz ke-4

Khalaf, Abdul Wahab, llmu Usul Fiqh. Kairo: Maktabah Al Da'wah al Islamiyah, 1990

Khatib, Mohammad Ajaj, Usul Al Hadis Ulumuhu wa Mustalahuhu. Dar al Fikr, tt, 1409 H/1989 M

Khinn, Mustafa Said al., 'tsar al-'Ikhtilaf fi al-Qawaid al-'Ushuliwah fi 'Ikhtilaf al-Fuqaha. Beirut: Mu'assasah al-Risalah, tahun 1972

Luweis, Abu, Al Muniid fi ai Luqhah. Beirut: Dar al Masyriq, tth

Majah, Ibnu, Sunan Ibnu Majah. Dar Ihya al-Turats al-'Arabi, tth. tt, jilid 2

Malik, Imam, Auza'al Masalik, (Beirut: Dar Fikr) Juz. 13, tt

Ma'luf, Lewis, al-Munjid fi al-Lugah wa al-A'lam. Beirut: Dar al-Masyriq, tahun 1975

Mawardi, Al, Al Ahkam Al Sulthaniyyah. Mesir Musthafa al Babi al Halabi, 1960

Muslim, Imam, Shahih Muslim. AI-Qohirah: Pen. Dar al-Hadits, tahun 1991, juz i

Nasa'i, Imam, Sunan al Nasa'i. Mesir Mustafa Babi al Halabi, juz 3, 1964 M 1394 H

Nawawi, Syarah Muslim. Mesir Matba'ah Misriyah, Juz 9, 1934

Nihayah al Muhtai. Dar al Fikr, Juz 7, tth, tt 
Rusydi, Ibnu, Bidavah AI-Mujtahid, Beirut: Dar al Fikr, Juz 2, tt

SA, Ramli, Drs., M.Ag., Muqaranah Madzahib fi al 'Ushul. Jakarta: Gaya Media Pratama, 1994

Sabiq, Sayid, Fiqh al-Sunnah. Beirut: Dar al-Masyriq, tt

Sayuti, al Asybah wa al Nazahir. Surabaya, tth.

Syafi'i, al Muhammad Idris, Al-Um, Mesir Al Faniyah AI-Muttahidah, Jilid 6, 1961

Syatabi, Imam al, al-Muwafaqat fi 'Ushul ai-Syari'ah, Mesir Dar al-Fikr al'Arabi, tth

Syiraji, Abu Ishaq al., AI-Muhadzab. Mesir Isa Al Bab al Halabi, tth, cet. ke dua

Tabari, al Abi Ja'far Muhammad Bin Jarir, Ikhtilaf al Fuqaha. Beirut: Dar Al-Kutub, tth.

Taimiyah, Ahmad Ibnu. Al-Sivasah al-Syar'iwah fi 'Ishlah al-Ra'i wa alRa'iyyah, (terjemahan Muh. Munawir Azahidi, Kebijakan Polrtik Nabi SAW), Surabaya: Dunia llmu, Cet I, 1418 H/1997 M

Warson Munawwir, Ahmad, Kamus Munawir Arab-Indonesia, Yogyakarta: Pustaka Progresif, tt, tth, Cet. I

Yanggo, Huzaemah Tahido, Pengantar Perbandingan Madzhab. Ciputat: Pen. Logos, cet. i, 1997

Zarqani, Muhammad Abd Azim al, Manahil al-'Irfan fi 'Ulum al-Qur'an, Beirut: Dar al-Fikr, tth., Jilid I. 